GEORGETOWN SCIENTIFIC RESEARCH JOURNAL
Volume Two Edition One Fall 2021

\title{
Impacts of Climate Change on Mycorrhizal Fungi in Salt Marsh Habitats
}

Cathilyn McIntosh, Gina Wimp, Ph.D. 


\title{
Impacts of Climate Change on Mycorrhizal Fungi in Salt Marsh Habitats
}

\author{
Cathilyn McIntosh, Gina Wimp \\ Department of Biology, Georgetown University, Washington D.C. \\ E-mail: clm315@georgetown.edu \\ https://doi.org/10.48091/gsr.v2i1.28
}

\begin{abstract}
Salt marshes are coastal wetlands that cover $2-3 \%$ of land surface area. ${ }^{1}$ These habitats carry out several essential functions such as providing habitats for many species, acting as a buffer between terrestrial land and ocean waters, and, most importantly, acting as a major carbon $(\mathrm{C})$ storage pool. Arbuscular mycorrhizal fungal $(\mathrm{AMF})$ symbionts are key organisms in salt marsh habitats and are known to influence the following processes and factors: plant zonation, plant resource competition, plant productivity, plant genetic diversity, soil $\mathrm{C}$ sequestration, soil C:N:P ratios, saprotrophic bacterial population and diversity, soil stability, and litter decomposition. Under rapidly changing conditions caused by climate change, it is difficult to predict how AMF communities will respond, ultimately altering these factors. This review will explain the role of AMF communities in modulating carbon sequestration by increasing plant and fungal biomass and influencing soil organic matter decomposition. Additionally, this review presents the current knowledge regarding how sea level rise (SLR), elevated $\mathrm{CO} 2$ levels, and eutrophication are expected to decrease AMF abundance and diversity by increasing habitat fragmentation, decompositional rates, anoxic conditions and altering soil nutrient stoichiometry. Studying soil fungi is essential for understanding how mycorrhizal communities are predicted to react to a climate change and, consequently, alter salt marsh processes.
\end{abstract}

Keywords: AMF, sea level rise, eutrophication, salt marsh

\section{Introduction}

Salt marshes are coastal wetlands that are consistently flooded and drained with salt water due to changing tides. These ecosystems are found worldwide and are often dominated by salt-tolerant smooth cordgrass which is essential for marsh stability. Additionally, salt marsh habitats perform a plethora of essential functions, such as acting as a buffer between terrestrial lands and ocean sea waters, providing habitats for coastal organisms, and most importantly, sequestering carbon (C) at unparalleled rates, which makes it an essential terrestrial $\mathrm{C}$ sink. ${ }^{2}$
Salt marsh C sequestration can largely be attributed to its high net primary production and decomposition cycle. It is estimated that the global net primary production from salt marsh vegetation is $0.44 \times 10^{15} \mathrm{~g} \mathrm{C}$ per year, equivalent to $440 \times 10^{6}$ metric tons of $\mathrm{C}$ per year. ${ }^{2}$ Only about $30 \%$ of this vegetation is consumed by herbivores, leaving the remaining $70 \%$, around 230 million metric tons of $\mathrm{C}$, to enter the decomposition cycle. ${ }^{2}$ However, frequent tidal flooding creates saline and anoxic conditions that slow decomposition, leading to a $\mathrm{C}$ storage rate that is $10-100$ times greater than terrestrial ecosystems. ${ }^{3}$ Regardless of the harsh saline 
and anoxic conditions, microbes, such as bacteria and fungi, play an essential role in the degradation of smooth cordgrass detritus, which significantly alters $\mathrm{C}$ sequestration rates. Therefore, understanding how these organisms mitigate $\mathrm{C}$ cycling and how they are affected by climatic variation is essential for predicting how salt marsh habitats will respond to climate change.

Salt marsh soils contain all three soil fungal types: symbiotrophs, pathotrophs, and saprotrophs. Symbiotrophs, particularly arbuscular mycorrhizal fungi (AMF), are extremely significant in salt marsh habitats due to their governance of biological processes. ${ }^{4} \mathrm{AMF}$ communities provide nutrients to their host plant in exchange for photosynthate..$^{5,6.7} \mathrm{It}$ has been found that AMF communities are able to maintain ecosystem balance and mitigate $\mathrm{C}$ sequestration by modulating soil organic matter (SOM) decomposition and nutrient mobilization. ${ }^{4}$ However, researchers have now provided evidence to suggest climate change is heavily impacting plantfungal interactions as well as bacterial-fungal interactions, both of which have a profound influence on $\mathrm{C}$ sinks and SOM decomposition. Rising sea levels due to increasing global surface temperatures are significantly impacting salt marsh elevation gradients, leading to the habitat fragmentation of Spartina patens, a key high-marsh grass. As elevation gradients decline, Spartina alterniflora, a foundational low-marsh grass species, is rapidly replacing $S$. patens. ${ }^{8}$ These geographical changes, as well as plant species zonation, have leverage over fungal communities consequently affecting decomposition rates. ${ }^{8}$

Soil-fungi interactions are also being remodeled by excessive mineral and nutrient fertilization, a process called eutrophication. This is mostly due to anthropogenic runoff from industrial waste and agricultural fertilizers entering coastal habitats. AMF's ability to acquire nutrients, decompose $\mathrm{SOM}$, and interact with rhizosphere bacteria and its host plant change depending on soil chemistry and nutrient abundance. ${ }^{4}$, 9,10 Hence, anthropogenic factors that have increased global surface temperatures, sea level rise (SLR), and eutrophication have had profound effects on microbial interactions in salt marsh ecosystems. ${ }^{10} \mathrm{In}$ this review, I will outline AMF's role in salt marsh habitats as well as describe their predicted reactions to climate change. Understanding how climate change impacts soil communities will allow us to better predict the outcomes of worsening climate conditions and employ more effective conservation plans in these areas.

\section{Mycorrhizal fungi in salt marsh ecosystems}

Arbuscular mycorrhizae (AMF) are extremely important mitigators of soil organic matter (SOM). Fungal species that are known to form AMF associations are in the genera Acaulospora, Entrophospora, Gigaspora, Glomus, Clecerocytis, and Scutellospora. ${ }^{11}$ These symbionts penetrate within the host plant's root cortical cells that form arbuscular sacs, allowing for nutrient exchange. Furthermore, mycorrhizae extend their hyphae into the soil creating mycelial networks that increase root surface area which improves nutrient acquisition of nitrogen $(\mathrm{N})$, phosphorus $(\mathrm{P})$, improves plant stability in soil, as well as bolsters plant pathogen resistance. ${ }^{10} \mathrm{In}$ return, host plants provide mycorrhizae with 10$20 \%$ of their net photosynthate (fixed C compounds). ${ }^{5,6,7}$

One of the main influential factors in determining AMF association is environmental conditions and micro-climate. Anoxic conditions increase with soil depth, thereby limiting AMF communities to upper soil layers which contain burrowing organisms and fluctuating water tables that provide enough aeration to support mycorrhizal colonization. ${ }^{12}$ Hence, elevated grass species, $S$. patens, can host AMF communities and have root colonization rates between $52-68 \%{ }^{13,14}$ On the other 
hand, S. alterniflora, a low, submerged grass with relatively anoxic soils, has root colonization rates of $0-9 \% .^{14,15,16}$

Marsh elevation also impacts nutrient availability which alters trade-offs in mutualistic investment. In elevated areas, reduced tidal inundation causes unpredictable nutrient import, resulting in $S$. patens to rely on its $\mathrm{AMF}$ association to acquire sufficient amounts of $\mathrm{N}$ and P. ${ }^{17}$

Conversely, low marsh grasses are constantly submerged, allowing $S$. alterniflora to have reliable sources of $\mathrm{N}$ and $\mathrm{P}$. If nutrients are readily available, the benefit received from AMF association is low, but the association still remains energetically costly, making the symbiont more parasitic than mutualistic. ${ }^{12}$

Additionally, studies have found that plantfungal associations and community composition differ based on the genetic specificity of both AMF and host plants. Van Der Heijden et al. (1998) ${ }^{18}$ was able to show that plants not only respond to the presence of $\mathrm{AMF}$, but response varies amongst fungal taxa. This would suggest that AMF diversity and taxonomic specificity for certain plants have the ability to alter host plant responses. ${ }^{18}$ Other studies, like Koch et al $(2006)^{19}$, further examined this phenomenon by observing plant responses in relation to intraspecific genetic diversity in isolates from one Glomus intraradices population. They found that AMF genetic diversity was able to affect plant species richness, growth, and productivity. ${ }^{19}$ Intraspecific variation within a single plant species has also been shown to alter AMF community composition. Eppley et al. (2009) ${ }^{20}$ found that different sexes of salt grass Distichlis spicata (with both sexes having the same growth rate) had dissimilar AMF colonization rates, suggesting host plant intraspecific genetic variation can alter $\mathrm{AMF}$ diversity and abundance. With climate change shifting plant community composition in salt marshes (i.e., replacement of $S$. patens patches by $S$. alterniflora) then we should expect there to be drastic changes to AMF species richness as well as genetic diversity. This will likely have significant impacts on SOM decomposition leading to altered C sequestration rates. Additionally, below ground alterations to fungal communities due to climate change will likely alter above ground responses in host plants.

\section{Mycorrhizal fungi mitigating $\mathrm{C}$-cycling and decomposition}

Because salt marshes have incredibly high net primary productivity and litter accumulation rates, AMF mitigation of saprotrophic bacteria and SOM decomposition is essential for $\mathrm{C}$-cycling. ${ }^{2,} \quad 21$ Research has shown that AMF communities can either stimulate or stunt $\mathrm{C}$ sequestration, depending on environmental conditions. However, there is debate as to how new climate conditions will alter these processes and whether they will lead to soil $\mathrm{C}$ storage or $\mathrm{C}$ release.

$\mathrm{AMF}$ stimulation of $\mathrm{C}$ sequestration can occur through soil aggregation, which is the binding together of micro-and macro-soil particles bound by cohesive forces or organic matter. Mycorrhizae promote soil aggregation by releasing binding agents, such as glomalin-related soil proteins that entangle soil macro-aggregates in dense hyphal networks. ${ }^{22}$ Once macro-aggregates are stabilized, micro-aggregates can form, allowing mycelial networks to physically protect $\mathrm{C}$ pools and increase $\mathrm{C}$ retention. ${ }^{22}$ This enmeshment also harbors a large portion of soil microbial biomass and accounts for a large portion of the SOM C pool. ${ }^{23}$ Improved nutrient acquisition due to $\mathrm{AMF}$ association can support higher amounts of above- and belowground plant biomass. Consequently, this increase in living and dead organic matter adds to the overall $\mathrm{C}$ sink. ${ }^{24,25}$

The exact mechanism of AMF decomposition is not completely understood, but there are a few 
proposed mechanisms. It is thought that mycorrhizal communities excrete hydrolytic enzymes, such as cellulase, pectinase, and xyloglucanase. ${ }^{22}$ However, there is no direct evidence to support that these extracellular enzymes have saprotrophic abilities. Another more supported hypothesis is priming, which is AMF's ability to manipulate rhizosphere microbial communities indirectly thereby affecting decompositional rates. Mycorrhizae emit labile $\mathrm{C}$ exudates into the soil which stimulate saprotrophic bacterial accumulation, SOM decomposition, and $\mathrm{CO}_{2}$ release. ${ }^{24}$ This causes a release of ammonium $\left(\mathrm{NH}_{4}{ }^{+}\right)$ that $\mathrm{AMF}$ rapidly absorbs and transfers to its host plant. ${ }^{10,21,26}$ Mycorrhizal access to both host plant C and soil $\mathrm{C}$ may make $\mathrm{AMF}$ communities better rhizosphere competitors, allowing them to alter soil microbe composition. ${ }^{12}$ Changing microbial communities would likely lead to shifts in important functional groups such as nitrogen fixation. As a result, altering the diversity and abundance of organisms responsible for important functional processes would have ramifications on soil nutrient levels, plant productivity rates, and plant community structures. ${ }^{12}$

\section{Effects of ambient $\mathrm{CO}_{2}$ levels and sea level rise}

Recent anthropogenic activities have caused ambient $\mathrm{CO}_{2}$ levels to rise significantly, which has coincided with higher-than-average global surface temperatures. ${ }^{27}$ This has led to an net decrease in total sea ice, which has ultimately caused global sea levels to rise $0.19 \mathrm{~m}$ from 1901 to $2010 .^{28}$

SLR will have profound consequences for salt marsh ecosystems. As described before, $S$. patens, a high elevation grass, and $S$. alterniflora, a low elevation grass, exist at limited elevation ranges relative to mean sea levels. ${ }^{29}$ Our current rate of SLR is estimated to be approximately $2.5 \mathrm{~mm}$ per year. However, through peat accumulation and sediment aggregation, salt marshes gain elevation and can vertically increase $2.08 \mathrm{~mm}$ to $4.20 \mathrm{~mm}$ each year, allowing them to remain above rising sea levels. ${ }^{29}$ Furthermore, elevated ambient $\mathrm{CO}_{2}$ levels are shown to bolster soil accretion and elevation gain. ${ }^{30}$ Elevated $\mathrm{CO}_{2}$ levels amplify plant growth and photosynthate production, resulting in an increase in fixed $\mathrm{C}$ allocations to mycorrhizae, increasing root and fungal biomass. ${ }^{10}$ Under higher $\mathrm{CO}_{2}$ levels, heightened plant growth demands stimulate additional $\mathrm{C}$ allocation to $\mathrm{AMF}$ communities in order to support nutrient mining. In terrestrial systems, elevated $\mathrm{CO}_{2}$ levels (550-700 p.p.m.) caused AMF density to increase by $84 \% .{ }^{31}$ These results support Langley et al. (2009) ${ }^{30}$ which found that root thickness increased to $4.9 \mathrm{~mm}$ per year under supplemental $\mathrm{CO}_{2}$ levels compared to $0.7 \mathrm{~mm}$ per year under normal ambient $\mathrm{CO}_{2}$ conditions. If SLR rates and marsh elevation gain remain unchanged, it is predicted that salt marsh ecosystems will be able to persist into the next century. ${ }^{29}$

Although greater biomass and soil accretion rates may seem to negate the issue of SLR, these modified conditions may change the biological mechanisms that govern $\mathrm{C}$ sequestration and decomposition. For example, photosynthesis rates diminish with each marginal increase in $\mathrm{CO}_{2}$ concentration, leading to changes in carbohydrate allocations to AMF communities. ${ }^{30}$ Research has shown that under elevated $\mathrm{CO}_{2}$ levels, mycorrhizal communities exhibit amplified rates of SOM decomposition. ${ }^{10}$ Studies have also observed escalating $\mathrm{N}$ mobilization rates, suggesting that priming and decomposition rates also increased, leading to soil $\mathrm{C}$ losses. ${ }^{26,} 10$ Moreover, the assumption that marsh soil accretion rates neutralize flooding from SLR rests on the assumption that SLR rates will remain stagnant. However, with increasing ambient $\mathrm{CO}_{2}$ concentrations, SLR rates are expected to increase, thereby surpassing the speed of soil accretion. ${ }^{28}$ Increasing litter accumulation will also alter soil chemistry which is 
an important predictor of AMF's relationships with plants and saprotrophic bacterial communities as well AMF's regulation of decomposition rates.

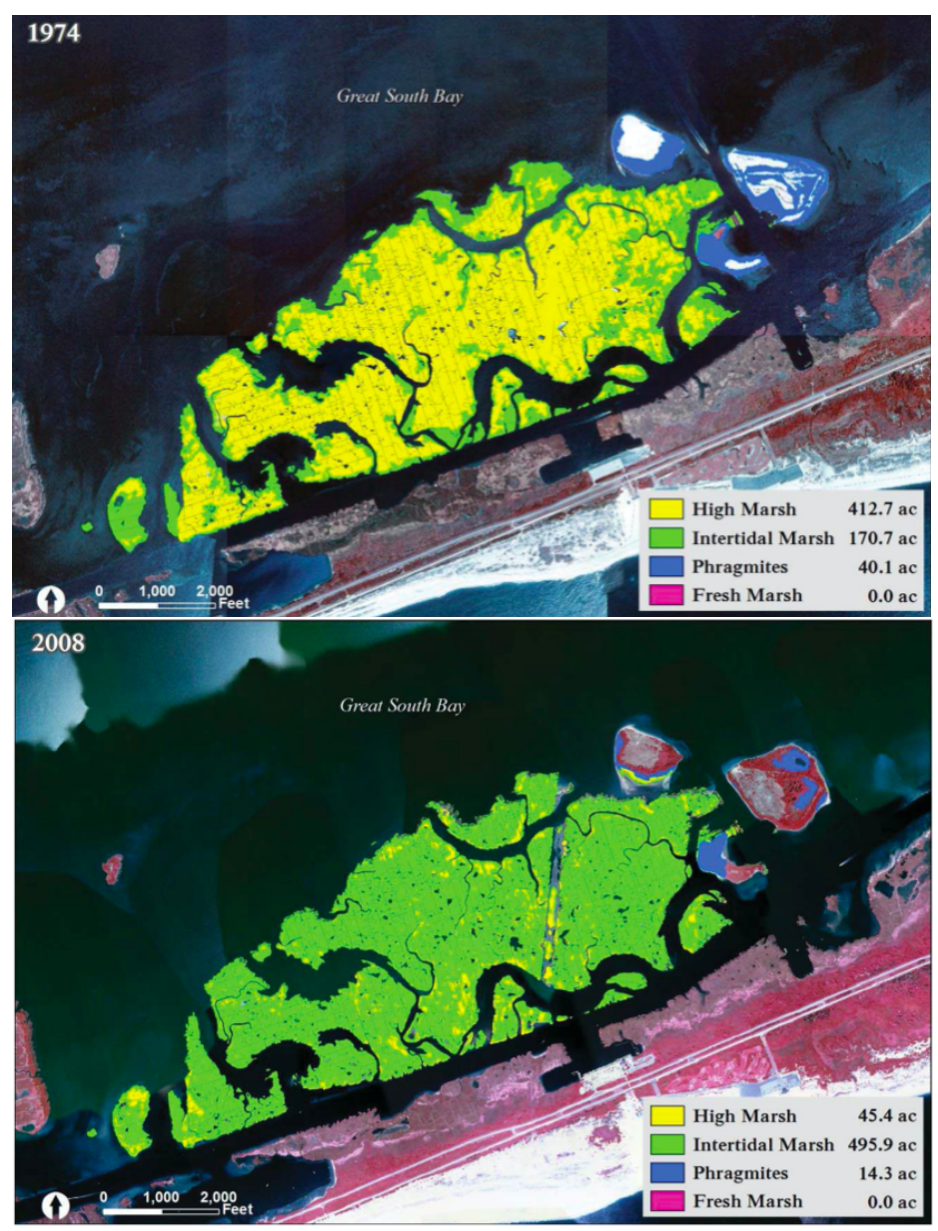

Figure 1. Differences in marsh elevation in the Cedar \& Nezera Islands near Long Island NY from 1974 (top) to 2008 (bottom). 1974 displays a high percentage of high marsh habitat (412.7 ac) compared to 2008 (45.4 ac). Adapted from Cameron Engineering \& Associates, 2015. ${ }^{32}$

Habitat loss due to human development of shorelines also has added additional pressures on marsh habitats. In the past, salt marsh grasses have been able to escape the threats of SLR by retreating to and colonizing higher elevation areas; but the development of shorelines has obstructed salt marsh grass migration. ${ }^{29}$ Figure 1 shows plant composition in the Cedar and Nezera Islands, near the Long Island tidal wetlands, in 1974 (top) and 2008 (bottom). ${ }^{32}$ The figure reveals that in 2008, there were more intense regions of fresh marsh development indicated by the darker pink. Moreover, Figure 1 displays the extreme fragmentation of $S$. patens (yellow) and the domination of $S$. alterniflora (green). This phenomenon has been experienced across many North American salt marshes and is not specific to this location. Since 1974, the presence of $S$. patens has decreased by 68\%; in 1974 the Cedar and Nezera Islands consisted primarily of high marsh habitat (412.7 acres) but in 2008 , only $11 \%$ of high marsh elevation remained ( 45.4 acres). It is important to restate that $\mathrm{AMF}$ associations are host-specific and non-resistant to the anoxic conditions of submerged marsh soils. Therefore, these changes would lead to reduced species richness and shifts in community composition of $\mathrm{AMF}{ }^{33}$ perhaps causing the extirpation of a particular taxon or a bottleneck effect on AMF genetic diversity.

\section{Effects of Eutrophication}

Eutrophication is characterized by excessive plant and algal growth due to fertilization of limiting growth factors such as $\mathrm{N}$ and $\mathrm{P} .{ }^{34}$ Eutrophication occurs naturally, but anthropogenic activities, such as sewage runoff and agricultural activities, have amplified this effect. ${ }^{34}$ Fertilization of salt marshes greatly transfigures soil $\mathrm{C}: \mathrm{N}: \mathrm{P}$ stoichiometry affecting AMF-plant relationships. Numerous studies have found opposing results on how eutrophication affects AMF's responses to grass zonation, microbial populations, decomposition, and $\mathrm{C}$ storage, making it difficult to predict how nutrient adjustments will alter AMF governed factors.

Studies have predicted that anthropogenic addition of $\mathrm{N}$ and $\mathrm{P}$ will shift plant competitive 
dominance as nutrient addition alters nutrient foraging rates, fungal-plant relationships, and fungal-bacterial interactions. ${ }^{35}$ Experimental additions of $\mathrm{N}$ to $S$. patens and $S$. alterniflora patches displayed a reduction in below-ground root biomass, but an increase in above-ground biomass, suggesting that nutrient foraging was eased. ${ }^{9,36,37}$ In addition to shifts in biomass production, other studies found that $\mathrm{N}$ addition caused spore biovolume and density of extraradical hyphae to decrease. ${ }^{10}, 33,38$ These observations are consistent with the resource-ratio hypothesis, which states that more competitive and successful species will grow in habitats with lower resource levels. It also suggests that when limitations are eased, competition for resources will shift from below-ground to above-ground. ${ }^{39}$ For example, when $\mathrm{N}$ limitations below-ground are reduced, plants are likely to increase above-ground production to compete for light. ${ }^{35}$ Under typical conditions, $\mathrm{AMF}$ allows $S$. patens to be competitively dominant in a resource limited environment. However, as $\mathrm{N}$ limitations are eased, and above-ground growth is increased, S. alterniflora is more successful and energy-efficient. ${ }^{35}$ For $S$. patens, as soil nutrient levels increase, nutrient foraging services greatly diminish causing it to be more parasitic than mutualistic. ${ }^{35,40}$ However, more recent studies found conflicting results in that $\mathrm{N}$ addition to salt marsh plots did not display signs of increased above-ground biomass. ${ }^{41}$ More research regarding eutrophication's influence on above- and below-ground biomass allocation should be investigated.

There is also debate about the effects of $\mathrm{N}$ addition on elevation gradients and decomposition rates in marsh habitats. Past studies have found that $\mathrm{N}$ addition promotes above-ground biomass and decomposition rates. ${ }^{9}{ }^{36} \mathrm{As} \mathrm{N}$ is added to soils, there is a subsequent release of $\mathrm{CO}_{2}$, indicating there is an increase in microbial respiration. ${ }^{37}$ This is likely due to a reduction in bacterial-fungal competition. As
AMF biomass diminishes with increasing $\mathrm{N}$ addition, competition for $\mathrm{N}$ between fungi and saprotrophic bacteria is eased, leading to an increase in bacterial populations and decompositional activities. ${ }^{42}$ Studies have found that, under these conditions, plants produced lower amounts of polyphenols, which regulate soil microbes that were likely linked to their overall observation of increased $\mathrm{CO}_{2}$ soil emissions. ${ }^{1}$ Furthermore, it was observed that for every atom of nitrogen added to salt marsh soils, 6.1 moles of $\mathrm{CO}_{2}$ were released. ${ }^{42}$ These changes in decomposition rates may negatively affect the soil accretion rates that protect salt marsh habitats from SLR. Yet, more recent studies report that $\mathrm{N}$ addition to salt marsh plots did not display signs of increased above-ground biomass. ${ }^{41}$ While this study did find that fertilization increased respiration rates, decomposition rates remained stagnant. $^{41}$

$\mathrm{N}$ enrichment alone is not the sole determinant in salt marsh grass root biomass. ${ }^{9}$ In P-limited soils, $\mathrm{N}$ enrichment increases $\mathrm{AMF}$ root colonization, spore biovolume, and density of extraradical hyphae. ${ }^{10} \mathrm{~N}$ enrichment to $\mathrm{P}$-limited soils increases plant biomass as it shifts soil $\mathrm{N}: \mathrm{P}$ ratios leading to $\mathrm{P}$ limitations. ${ }^{10}$ But, most saline marine systems are $\mathrm{N}-$ limited and $\mathrm{P}$-rich meaning $\mathrm{N}$ addition would cause AMF associations to be unbeneficial because of a decrease in competition with soil mircobes. ${ }^{36}$ Future research is needed to accurately predict how eutrophication will affect these ecosystems long term and elucidate conflicting results.

\section{Conclusion}

AMF fungal communities are foundational species in salt marsh habitats, moderating $\mathrm{C}$ sequestration, plant zonation, nutrient acquisition, soil stability, microbial populations, and decomposition. Recent anthropogenic activities have elevated ambient $\mathrm{CO}_{2}$ levels, leading to SLR which poses risks to plant community structure as 
well as AMF processes..$^{10,26,27}$ SLR is predicted to diminish AMF abundance, increase decomposition and diminish $\mathrm{C}$ pools. ${ }^{10}$ Furthermore, anthropogenic $\mathrm{N}$ fertilization of marsh soils has led to decreased root and fungal biomass causing competition to shift from below-ground to aboveground. ${ }^{39}$ Additionally, it is believed that reductions in AMF biomass and increased $\mathrm{N}$ availability will increase microbial respiration and decomposition rates. However, there is still debate about how decomposition rates are impacted by $\mathrm{N}$ fertilization. ${ }^{41}$ Additional research should be conducted to elucidate the exact mechanisms of AMF driven decomposition, which would allow us to create a clearer picture of how decompositional processes function in salt marsh habitats. Moreover, future studies should observe how climate change conditions such as elevated $\mathrm{CO}_{2}$ levels, SLR, and eutrophication will impact AMF and plant community structures, decompositional rates, and $\mathrm{C}$ storage rates in order to create more consistent results within the current literature as well as provide more concrete directions for conservation efforts.

\section{Acknowledgments}

This work was supported by Georgetown's Center for Research and Fellowships - Kalorama Fellowship.

\section{References}

1. Bragazza, L., Freeman, C., Jones, T., Rydin, H., Limpens, J., Fenner, N., Ellis, T., Gerdol, R., Hajek, M., Hajek, T., Iacumin, P., Kutnar, L., Tahvanainen, T., \& Toberman, H. (2006).

Atmospheric nitrogen deposition promotes carbon loss from peat bogs. Proceedings of the National Academy of Sciences, 103(51), 19386-19389. https://doi.org/10.1073/pnas.0606629104

2. Raghukumar, S. (2017). The Salt Marsh Ecosystem. In S. Raghukumar, Fungi in Coastal and Oceanic Marine Ecosystems (pp. 87-101). Springer International Publishing. https://doi.org/10.1007/978-3-319-54304-8 6
3. Chmura, G. L. (2013). What do we need to assess the sustainability of the tidal salt marsh carbon sink? Ocean \& Coastal Management, 83, 25-31.

4. Zhang, G., Bai, J., Tebbe, C. C., Huang, L., Jia, J., Wang, W., Wang, X., Yu, L., \& Zhao, Q. (2021). Spartina alterniflora invasions reduce soil fungal diversity and simplify co-occurrence networks in a salt marsh ecosystem. Science of The Total Environment, 758, 143667. https://doi.org/10.1016/j.scitotenv.2020.143667

5. Treseder, K. K. (2004). A meta-analysis of mycorrhizal responses to nitrogen, phosphorus, and atmospheric $\mathrm{CO}_{2}$ in field studies. New Phytologist, 164(2), 347-355. https://doi.org/10.1111/j.14698137.2004.01159.x

6. Barea, J.-M., Ferrol, N., Azcón-Aguilar, C., \& Azcón, R. (2008). Mycorrhizal symbioses. In P. J. White \& J. P. Hammond (Eds.), The Ecophysiology of Plant-Phosphorus Interactions (Vol. 7, pp. 143-163). Springer Netherlands. https://doi.org/10.1007/9781-4020-8435-5 7

7. Shah, F., Nicolás, C., Bentzer, J., Ellström, M., Smits, M., Rineau, F., Canbäck, B., Floudas, D., Carleer, R., Lackner, G., Braesel, J., Hoffmeister, D., Henrissat, B., Ahrén, D., Johansson, T., Hibbett, D. S., Martin, F., Persson, P., \& Tunlid, A. (2016). Ectomycorrhizal fungi decompose soil organic matter using oxidative mechanisms adapted from saprotrophic ancestors. New Phytologist, 209(4), 1705-1719. https://doi.org/10.1111/nph.13722

8. Rippel, T. M., Mooring, E. Q., Tomasula, J., \& Wimp, G. M. (2020). Habitat edge effects decrease litter accumulation and increase litter decomposition in coastal salt marshes. Landscape Ecology, 35(10), 2179-2190. https://doi.org/10.1007/s10980-02001108-3

9. Darby, F., \& Turner, R. (2008). Effects of eutrophication on salt marsh root and rhizome biomass accumulation. Marine Ecology Progress Series, 363, 63-70. https://doi.org/10.3354/meps07423

10. Johnson, N. C., Angelard, C., Sanders, I. R., \& Kiers, E. T. (2013). Predicting community and ecosystem outcomes of mycorrhizal responses to global change. Ecology Letters, 16, 140-153. https://doi.org/10.1111/ele.12085 
11. Schenck, N. C., \& Perez, Y. (1990). Manual for the identification of VA mycorrbizal fungi (Vol. 286). Synergistic Publications Gainesville.

12. Welsh, A. K., Burke, D. J., Hamerlynck, E. P., \& Hahn, D. (2010). Seasonal analyses of arbuscular mycorrhizae, nitrogen-fixing bacteria and growth performance of the salt marsh grass Spartina patens. Plant and Soil, 330(1-2), 251-266. https://doi.org/10.1007/s11104-009-0197-5

13. Hoefnagels, M. H., Broome, S. W., \& Shafer, S. R. (1993). Vesicular-Arbuscular Mycorrhizae in Salt Marshes in North Carolina. Estuaries, 16(4), 851. https://doi.org/10.2307/1352444

14. d'Entremont, T. W., López-Gutiérrez, J. C., \& Walker, A. K. (2018). Examining Arbuscular Mycorrhizal Fungi in Saltmarsh Hay (Spartina patens) and Smooth Cordgrass (Spartina alterniflora ) in the Minas Basin, Nova Scotia. Northeastern Naturalist, 25(1), 72-86. https://doi.org/10.1656/045.025.0107

15. Pratt-Zossoungbo, M., \& Biber, P. D. (2009). Inoculation and Colonization of Four Saltmarsh Species with Vesicular-Arbuscular Mycorrhizal Fungi (Mississippi). Ecological Restoration, 27(4), 387-389. JSTOR.

16. Burcham, A. K., Merino, J. H., Michot, T. C., \& Nyman, J. A. (2012). Arbuscular Mycorrhizae Occur in Common Spartina Species. Gulf of Mexico Science, 30(1). https://doi.org/10.18785/goms.3001.03

17. Burke, D. J., Hamerlynck, E. P., \& Hahn, D. (2002). Effect of arbuscular mycorrhizae on soil microbial populations and associated plant performance of the salt marsh grass Spartina patens. Plant and Soil, 239(1), 141-154.

18. Van Der Heijden, M. G. A., Boller, T., Wiemken, A., \& Sanders, I. R. (1998). Different arbuscular mycorrihizal fungal species are potential determinants of plant community structure. Ecology, 79(6), 2082-2091. https://doi.org/10.1890/00129658(1998)079[2082:DAMFSA]2.0.CO;2

19. Koch, A. M., Croll, D., \& Sanders, I. R. (2006). Genetic variability in a population of arbuscular mycorrhizal fungi causes variation in plant growth: Functional variability in AMF populations. Ecology Letters, 9(2), 103-110. https://doi.org/10.1111/j.1461-0248.2005.00853.x
20. Eppley, S. M., Mercer, C. A., Haaning, C., \& Graves, C. B. (2009). Sex-specific variation in the interaction between Distichlis spicata (Poaceae) and mycorrhizal fungi. American Journal of Botany, 96(11), 1967-1973. https://doi.org/10.3732/ajb.0900076

21. Frey, S. D. (2019). Mycorrhizal fungi as mediators of soil organic matter dynamics. Annual Review of Ecology, Evolution, and Systematics, 50, 237-259.

22. Wei, L., Vosátka, M., Cai, B., Ding, J., Lu, C., Xu, J., Yan, W., Li, Y., \& Liu, C. (2019). The Role of Arbuscular Mycorrhiza Fungi in the Decomposition of Fresh Residue and Soil Organic Carbon: A MiniReview. Soil Science Society of Amer

23. Wilson, G. W. T., Rice, C. W., Rillig, M. C., Springer, A., \& Hartnett, D. C. (2009). Soil aggregation and carbon sequestration are tightly correlated with the abundance of arbuscular mycorrhizal fungi: Results from long-term field experiments. Ecology Letters, 12(5), 452-461. https://doi.org/10.1111/j.1461-0248.2009.01303.x

24. Daynes, C. N., Field, D. J., Saleeba, J. A., Cole, M. A., \& McGee, P. A. (2013). Development and stabilisation of soil structure via interactions between organic matter, arbuscular mycorrhizal fungi and plant roots. Soil Biology and Biochemistry, 57, 683694. https://doi.org/10.1016/j.soilbio.2012.09.020

25. Verbruggen, E., Veresoglou, S. D., Anderson, I. C., Caruso, T., Hammer, E. C., Kohler, J., \& Rillig, M. C. (2013). Arbuscular mycorrhizal fungi - shortterm liability but long-term benefits for soil carbon storage? New Phytologist, 197(2), 366-368. https://doi.org/10.1111/nph.12079

26. Cheng, L., Booker, F. L., Tu, C., Burkey, K. O., Zhou, L., Shew, H. D., Rufty, T. W., \& Hu, S. (2012). Arbuscular Mycorrhizal Fungi Increase Organic Carbon Decomposition Under Elevated CO2. Science, 337(6098), 1084-1087. https://doi.org/10.1126/science.1224304

27. Allen, M.R., O.P. Dube, W. Solecki, F. AragónDurand, W. Cramer, S. Humphreys, M. Kainuma, J. Kala, N. Mahowald, Y. Mulugetta, R. Perez, M. Wairiu, and K. Zickfeld, 2018: Framing and Context. In: Global Warming of $1.5^{\circ} \mathrm{C}$. An IPCC Special Report on the impacts of global warming of $1.5^{\circ} \mathrm{C}$ above pre-industrial levels and related global 
greenhouse gas emission pathways, in the context of strengthening the global response to the threat of climate change, sustainable development, and efforts to eradicate poverty [Masson-Delmotte, V., P. Zhai, H.-O. Pörtner, D. Roberts, J. Skea, P.R. Shukla, A. Pirani, W. Moufouma-Okia, C. Péan, R. Pidcock, S. Connors, J.B.R. Matthews, Y. Chen, X. Zhou, M.I. Gomis, E. Lonnoy, T. Maycock, M. Tignor, and T. Waterfield (eds.)]. In Press.

28. IPCC, 2014: Climate Change 2014: Synthesis Report. Contribution of Working Groups I, II and III to the Fifth Assessment Report of the Intergovernmental Panel on Climate Change [Core Writing Team, R.K. Pachauri and L.A. Meyer (eds.)]. IPCC, Geneva, Switzerland, $151 \mathrm{pp}$.

29. Crosby, S. C., Sax, D. F., Palmer, M. E., Booth, H. S., Deegan, L. A., Bertness, M. D., \& Leslie, H. M. (2016). Salt marsh persistence is threatened by predicted sea-level rise. Estuarine, Coastal and Shelf Science, 181, 93-99.

https://doi.org/10.1016/j.ecss.2016.08.018

30. Langley, J. A., McKee, K. L., Cahoon, D. R., Cherry, J. A., \& Megonigal, J. P. (2009). Elevated $\mathrm{CO} 2$ stimulates marsh elevation gain, counterbalancing sea-level rise. Proceedings of the National Academy of Sciences, 106(15), 6182-6186. https://doi.org/10.1073/pnas.0807695106

31. Talbot, J. M., Allison, S. D., \& Treseder, K. K. (2008). Decomposers in disguise: Mycorrhizal fungi as regulators of soil $\mathrm{C}$ dynamics in ecosystems under global change. Functional Ecology, 22(6), 955-963. https://doi.org/10.1111/j.1365-2435.2008.01402.x

32. Cameron Engineering \& Associates,. (2015). Long Island Tidal Wetlands Trends Analysis.

https://www.dec.ny.gov/docs/fish_marine_pdf/bmrw etlandstrends1.pdf

33. Liu, Y., Shi, G., Mao, L., Cheng, G., Jiang, S., Ma, X., An, L., Du, G., Collins Johnson, N., \& Feng, H. (2012). Direct and indirect influences of $8 \mathrm{yr}$ of nitrogen and phosphorus fertilization on Glomeromycota in an alpine meadow ecosystem. New Phytologist, 194(2), 523-535. https://doi.org/10.1111/j.1469-8137.2012.04050.x

34. Chislock, M. F., Doster, E., Zitomer, R. A., \& Wilson, A. E. (2013). Eutrophication: Causes, consequences, and controls in aquatic ecosystems.
Nature Education Knowledge, 4(4), 10. https://doi.org/10.1016/j.ocecoaman.2011.09.006

35. Daleo, P., Alberti, J., Canepuccia, A., Escapa, M., Fanjul, E., Silliman, B. R., Bertness, M. D., \& Iribarne, O. (2008). Mycorrhizal fungi determine salt-marsh plant zonation depending on nutrient supply: Nutrients, AMF and salt marsh zonation. Journal of Ecology, 96(3), 431-437. https://doi.org/10.1111/j.1365-2745.2007.01349.x

36. Valiela, I., Teal, J. M., \& Persson, N. Y. (1976). Production and dynamics of experimentally enriched salt marsh vegetation: Belowground biomass1: Belowground salt marsh production. Limnology and Oceanography, 21(2), 245-252. https://doi.org/10.4319/lo.1976.21.2.0245

37. Crosby, S. C., Spiller, N. C., Healy, D. S., Brideau, L., Stewart, L. M., Vaudrey, J. M. P., Tietz, K. E., \& Fraboni, P. J. (2021). Assessing the Resiliency of Salt Marshes Under Increasing Nitrogen Loading. Estuaries and Coasts, 44(6), 1658-1670. https://doi.org/10.1007/s12237-021-00899-1

38. Zhang, T., Yang, X., Guo, R., \& Guo, J. (2016). Response of AM fungi spore population to elevated temperature and nitrogen addition and their influence on the plant community composition and productivity. Scientific Reports, 6(1), 24749. https://doi.org/10.1038/srep24749

39. Tilman, D. (1982). Resource Competition and Community Structure. (MPB-17), Volume 17. Princeton University Press. https://doi.org/10.1515/9780691209654

40. Bronstein, J. L. (1994). Conditional outcomes in mutualistic interactions. Trends in Ecology E Evolution, 9(6), 214-217. https://doi.org/10.1016/0169-5347(94)90246-1

41. Anisfeld, S. C., \& Hill, T. D. (2012). Fertilization Effects on Elevation Change and Belowground Carbon Balance in a Long Island Sound Tidal Marsh. Estuaries and Coasts, 35(1), 201-211. https://doi.org/10.1007/s12237-011-9440-4

42. Turner, R. E., Howes, B. L., Teal, J. M., Milan, C. S., Swenson, E. M., \& Tonerb, D. D. G. (2009). Salt marshes and eutrophication: An unsustainable outcome. Limnology and Oceanography, 54(5), 16341642 . 


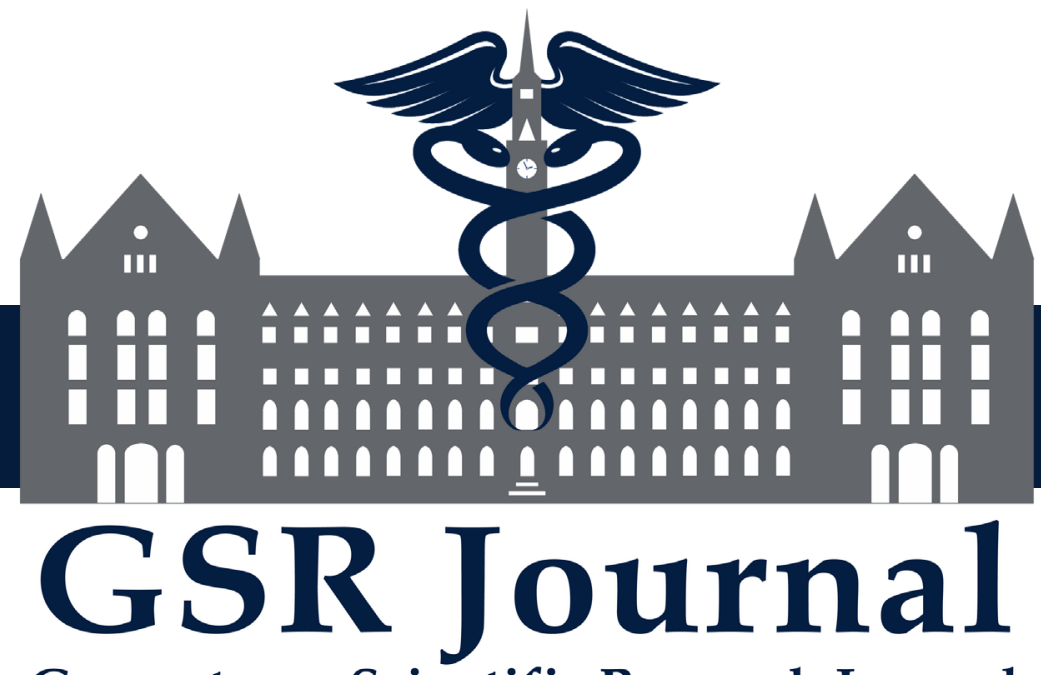

Georgetown Scientific Research Journal 